\title{
POLITICAL WILL AS A PRECONDITION FOR EFFECTIVE PARLIAMENTARY OVERSIGHT OF THE REPUBLIC OF MACEDONIA'S SECURITY SECTOR
}

\author{
Sevilj Muaremoska Abduli Ph.D. \\ Faculty for detectives and security, FON University - Skopje \\ E-mail: sevil.muaremoska@fon.edu.mk \\ Naser Etemi Ph.D \\ Faculty for detectives and security, FON University - Skopje \\ E-mail: naser.etemi@fon.edu.mk
}

\begin{abstract}
The political will is an essential prerequisite for achieving effective parliamentary control. The importance of this requirement is especially emphasized in the countries with fragile democracies where the members of the parliamentary majority refer to as "party soldiers" to the interests of the mother party which is put before the social interests of the state and thus intellectually do not penetrate deep into the core of specific questions to control if they do not concern their political party. There are several factors that influence the (non) existence of political will of lawmakers to perform effective oversight of the security sector. The problem of (non) existence of the political will of lawmakers is closely connected to the (non) existence of the authority of parliament as an institution, also the (non) existence of the personal integrity of parliamentarians, and the degree of democracy and professionalism of deputies, especially with the political priorities which are put ahead by deputies and so on.

This paper will elaborate in detail the importance of the political will to implement effective parliamentary control of the security sector. At the same time we will try to propose a way to minimize partisanship, politicization and the abuse in the functioning and implementation of mechanisms of parliamentary control of the security sector in a way that political will is a prerequisite for more effective parliamentary control, not a factor in the tactics and defocus of the control function of the parliament because of various political interests.
\end{abstract}


Keywords: political will, parliament, parliamentary control, security sector.

\section{Introduction}

Parliamentarism, as a product of the new century that historically originated in the British Isles, is a form of organization of power in which the relations among the state authorities are based on the principle of flexible separation of powers, as expressed through the equality of state governments through the cooperation of the legislative and executive and by having means for their mutual influence (Klimoski, 2007:379).

Parliament as a central institution of the parliamentary system is present in all pluralistic regimes without exception. In XIX century the parliament was considered the ruler of the country, but a number of factors have caused the power of parliament to pass in pursuit. Except as representative and as a constituent and legislative body, the Assembly of the Republic Macedonia also has two very important functions, such as: choice and control function.

- The Optional feature of the Assembly derives from its constitutional options, provided in Article 68 of the Constitution of the Republic Macedonia, to choose the members of the Government, judges of the Constitutional Court, members of the Judicial Council, judges, People's Attorney, prosecutor and the election, appointment and dismissal of other public functions established by certain laws.

- Control function - this function applies to constitutional opportunity for Parliament to exercise political control and supervision over the work of the Government and other public officials that are legally responsible to the Assembly of the Republic Macedonia. The control function of the Parliament is an important cornerstone for the democratic development of the country and prevention of arbitrariness and abuse in the exercise of constitutional and legal powers by the holders of power. Here I would mention the adoption of the budget as the most efficient means to control the work of the executive. Through the establishment of the funds available to the Government for the coming year, the Parliament has insight into the work of the Government in order proper and adequate budget spending. Other means of control of Parliament over the Government: parliamentary questions, interpellations, the question of confidence in the government, inquiries and oversight hearings. 
In this regard it should be highlighted the implications of the famous John Stuart Mill that the role of the Parliament does not mean he can run the country, but to insist the country to be ruled by the best individuals.

The basic question that arises in this regard is which are the necessary democratic conditions for realization of the role of Parliament in the control and supervision of the institutions of the executive.

\section{Basic requirements for conducting parliamentary control}

If you take into consideration that the main role of Parliament is to "pass laws, act as a representative body, to supervise and control the work of the executive, to train politicians and contributes to preserving the legitimacy of the political system (Heywood, 2012:7), then it is understandable the need for these prerequisites for effective parliamentary control of the security sector in Republic Macedonia: well-defined constitutional and legal powers, resources and expertise and the existence of political will.

- Constitutional and legal preconditions for parliamentary control of the security sector. The constitutional and legal powers represent the first and most important prerequisite for the exercise of parliamentary control over the operations of the institutions of the executive. They originate from the basics of constitutional provisions then make the same more precise in specific legislation which create a kind of stable and healthy basis for the exercise of parliamentary activity, because "democracy must always be constitutional, the rules of the game must not be changed by the will of any majority, but they should be set as restrictions on the opinions and decisions and should be relatively immune to change (Joung, 1990: 93-94 ).

- Resources and expertise as prerequisites for parliamentary control. The key role in the exercise of parliamentary control have democratically elected members of parliament, which to respond to the challenge of monitoring and supervision need to have the necessary knowledge, skill and experience to exercise effective parliamentary control. But because such activity is a complex and extensive effort, often the inter parliamentary expertise is facing a shortage of staff in trying to implement effective parliamentary control and is much more smaller the number of parliamentarians that Parliament can rely in implementing specific form of control since diversity of scientific and professional spheres of coming parliamentarians. These difficulties are overcome by organizing appropriate training and education on effective use of the mechanisms of parliamentary control. But it involves a series of difficulties such as: (non) existence of political will (un) timely implementation of education and training (in) separation 
of funds for implementing education and training and a range of other problems that are mutually closely related considering the fact that the parliamentary mandate lasts a certain period after its completion changing and Parliament members, after which again requires political will for timely new training and thus separating new funds for its implementation. However, theory and practice are agreed in the view that effective parliamentary control is best achieved by means of additional infrastructure to include qualified professional staff that provides sound advice on government proposals and by engaging experts and independent researchers and institutions that will provide detailed and objective analysis (Lunn, 2003:36).

- Political will as a prerequisite for parliamentary control of the security sector. Political will is an essential prerequisite for achieving effective parliamentary control, which according to democratic rules of functioning of the legislative power is one of its basic obligations. The existence or lack of political will among parliamentarians is often tied to the party discipline of deputies - members of one or another political party that according to their party affiliation is or are not interested in performing essential control over the work of the security sector. This particularly applies to parliamentarians belonging to the ruling party that are mostly indifferent to the efforts of the opposition to trigger a control mechanism. Thus, consciously passive control function of the parliament of the interests of the party in power no matter which party thus concerned. To overcome this situation, parliaments need to find ways to make efforts to minimize partisanship, politicization and abuse in the functioning and implementation of mechanisms for parliamentary control of the institutions of the executive (including security sector institutions), more nimble and more firmly perform control function and explore ways to reform in order to strengthen this function.

\section{The political will to ensure efficient parliamentary control and oversight of the security sector}

Political will is an essential prerequisite for achieving effective parliamentary control, which according to democratic rules of functioning of the legislative power is one of its basic obligations. The existence or lack of political will among parliamentarians is often tied to the party discipline of deputies - members of one or another political party that according to their party affiliation is or are not interested in performing essential control over the work of the security sector. This particularly applies to parliamentarians belonging to the ruling party that are mostly indifferent to the efforts of the opposition to trigger a control mechanism. Thus, consciously passive control function of the parliament of the interests of the party in power no matter which party thus concerned. 
However, if we analyze a bit beyond, we see that there are several factors that influence the (none) existence of political will of lawmakers to perform effective oversight of the security sector. The problem of (none) existence of political will of lawmakers is closely connected to the (non) existence authority of parliament as an institution (non) existence of personal integrity of parliamentarians, the degree of democracy and professionalism of the deputies, and especially with political priorities ahead lay deputies and so on. So in countries in transition and those with fragile democracies the majority of parliamentarians, especially when their party is in power, show no desire to consistently carry out their parliamentary functions. Thus, as it is pointed out by Vankovska, Macedonian parliament reacts with delay on the situation and developments in the country, and the reasons for this kind of situation gives ability to locate the following disadvantages: Most of the lawmakers into "party soldiers" who strictly observe the party line and intellectually not penetrate deep into security issues. Then there is a shortage of civilians who have enough knowledge of security and defense; especially the parliament lacks expert staff.

Hence the fundamental problem is how to ensure greater interest of parliamentarians to the problems of citizens and accordingly how to reduce the influence of the party in their operations.

The lack of political will to control and oversight of the security sector can be a result of various factors, but most important are the party discipline and having or not having an interest in the "electorate" in parliament (Bakreski, 2008). Hence the problem of political will of lawmakers requires a serious, substantive and systematic approach to its solution. In order to provide such access must be analyzed the following key aspects that affect this situation in the Republic of Macedonia, which are:

- Electoral Model of the Republic of Macedonia. "The election system is one of the most important aspects of the parliamentary system having part in enabling or disabling the tyranny of the majority. The Republic of Macedonia is represented with the Dontov proportional system of closed lists, and the Republic of Macedonia is divided into six districts. Citizens vote for parties, and the selection of candidates is carried out by the parties themselves. According to this model, the candidates or political parties that won the most votes participate in the distribution of mandates. In this case, the citizen votes for a list of candidates (list of a political party or independent candidates) in which candidates receive mandates as many as received voices for their proposed list. This electoral system favors large parties and coalitions opposed to smaller ones. Thus, the possibility of disagreement in the caucuses themselves and any non-party compromise are minimized. Since deputies are accountable to the party that has made the electoral list and not directly to voters who voted that list. "Within the European Union only in $17 \%$ 
(three of 18) of the member states with a proportional electoral system by applying the so-called closed lists, as a way of selecting parliamentarians practiced in our country. In contrast to the Republic of Macedonia, in the majority of European countries practiced proportional electoral system with open lists. The system of open lists (in multiple modalities) is applied in $83 \%$ (15 of 18) European Union countries that have proportional system, this includes Sweden, Finland, Denmark, Belgium, Netherlands, Luxembourg, Austria, Czech Republic, Slovakia, Poland, Estonia, Slovenia, Greece and Cyprus. 65\% (22 of 34) of European countries that have proportional system, as it applies this system of open lists, here I would mention: Switzerland, Norway, Iceland, Bosnia and Herzegovina and Kosovo, and 44\% (33 of 75 ) of the countries in the world to have a proportional electoral system. The system of open lists, means voters to rank the candidates of their choice rather than as given by the initiator. This system allows voters, despite voting for the candidate list or the party/coalition to choose one or more candidates from the candidate list (so-called preferential voting) and thus influence the final choice. The greater the number of preferential votes has the voter, the greater the opportunity to influence the selection of candidates and greater competition among candidates for the votes of the electorate (Shishovski, Lechevska, et all, 2012). Thus reducing the influence of the party on the parliamentarians and the other by increasing their individual responsibility to the citizens who voted. Thus it is expected that between two election cycles the dominant focus of attention of the parliamentarians will be concerns and interests of citizens and they will more actively dealing with them in order to get as many votes in the next election.

- Intraparty democracy. Intraparty democracy has always been a challenge in emerging democracies (Cekov and Daskalovski, 2012), and is necessary to increase the impact and contribution of politically involved citizens in the party. Democratic state can not be governed by parties with undemocratic structures, because the parties actually mirror the situation in the system. If they lack democracy, dialogue, exchange of views and different opinions, it will definitely reflect the democratic capacity and quality of political institutions (Karakamiseva, 2008), and the democratic capacity and quality of society as a whole. In many countries there are legal directives to oblige parties to respect democratic procedures within their internal processes. In many countries, the constitution or laws oblige parties to form their internal processes according to democratic procedures. However, despite such provisions, in reality this is often overlooked and so the impact of "ordinary" party members is relatively limited circle of members who actually powerful and influential are usually very small. In Macedonia, similarly to other post-communist countries of South Eastern Europe, the legacy of the party culture in the past, such as the strong hierarchical tendencies within the party, non-competitive elections the party 
leadership and access top-down decision-making, still part of the party organization. These features of the intra-organization in Macedonia have their major impact on the development of democratic processes within the parties and beyond the country. In general, political parties in Macedonia most often identify with their leaders, as a result of central distribution of power within the party. In each of these circumstances is understandable the influence of parties on one proposed parliamentarian and their particular interest to operate exclusively in the direction of the established party platform even when they themselves do not agree with it, even when it is best for the citizens by which they were selected. The arguments that are in favor of the open list system show that it will contribute to greater party democracy, given that the selection of candidates will be decentralized to a large extent. An additional advantage is that this system favors the more capable candidates to take the needs and expectations of citizens, and therefore the party becomes more effective in achieving the expectations of citizens (Hofmeister and Grabow, 2012).

- The status of parliamentarians after the completion the post of a Parliamentarian. In accordance with Article 35 of the Law on parliamentarians, the parliamentarian who was employed until the election of an parliamentarian has the right within 30 days after the termination of the mandate to return to the workplace or other work which corresponds to the type and extent of his professional education. This general legal provision means that parliamentarians after the end of their term have no certainty with regard to their future professional career (Cekov, 2012). In this respect, the existing legal solution further binds parliamentarians for the party, especially those parliamentarians who have nowhere to return after completion of the post of a Parliamentarian. This particularly applies to those lawmakers before getting tenure had based permanent employment, and all other parliamentarians depending on the duration of their mandate some time been away from his profession.

As an additional obstacle in terms of strengthening the political will to performing and functioning in their belief and not exclusively under the baton of the party leadership and allegations that circulated in public for allegedly signed promissory notes for loyalty, guarantees and blank resignations by members of the party in power as a way to control and in the mildest form were told to direct the activities of parliamentarians in the implementation of the party's platform at any price. In the Law on parliamentarians of the Republic Of Macedonia is not legally regulated and expressly prohibited the possibility of signing bills of loyalty or blank resignations by members, although some attempts that were initiated by the opposition in 2009 when the "NSDP leader Tito Petkovski proposed amendments to the Law on deputies, that the execution of the Representative shall not be limited by material or financial guarantee to the political party or coalition whose 
candidate list is elected. In 2011 followed other such attempts to amend our existing legal solution, but again were not supported by the parliamentarians from the ruling party. Although such legislations are not unknown in the developed democracies, the legislature of the Republic of Macedonia did not find the strength to incorporate unambiguous statutory provision that would help protect the authority and integrity of the function as a parliamentarian.

\section{Conclusion}

In accordance with the aforementioned, we can conclude that the existence of strong political will of lawmakers to perform effective parliamentary control is the prerogative of the developed democratic societies. The problem with the political will of lawmakers requires a serious, substantive and systematic approach to its solution. The current concept of this phenomenon is a reflection of the existing democratic mechanisms and processes, such as the electoral system in the Republic of Macedonia and the need to change the existing with new proportional electoral system with open lists and single constituency on the whole territory of the Republic of Macedonia in order to reduce the impact of the party on the parliamentarians, and on the other hand to increase their individual responsibility to the citizens who voted; intraparty democracy as a prerequisite for increased influence of political involved citizens within the party and in society in general and the status of parliamentarians after the post of deputy in the direction of increased reliability of lawmaker after his tenure as indirectly produces relaxation of relations between lawmaker and the party that nominated him. Currently these are the key segments where the biggest weaknesses are detected, but also opportunities for enhancing and strengthening the political will to implement efficient and effective parliamentary control of the security sector of the Republic of Macedonia.

\section{Bibliography}

\section{Books}

1. Bakreski, 0. (2008) Control of the security sector. Skopje: Faculty of Philosophy. Cekov A., Daskalovski H. (2012) Analysis of intra-party democracy in Macedonia. Skopje: Center for Research and Policy, Konrad Adenauer.

2. Heywood, A. (2004) Politic. Belgrade: CLIO.

3. Hofmeister W. Grabow K. (2012) Political parties: funktions and organization in democratic societies. Skopje: Konrad Adenauer Stiftung in Republic of Macedonia.

4. Joung, I. (1990) Justice and Politics of Difference, Princeton: Princeton University press. 
5. Klimoski S. (2007) Constitutional Law and Political System. Skopje: Enlightenment.

6. Klimovski, S. (2009) Constitutional Law. Skopje: Enlightenment AD Skopje.

7. Rokviћ, V. (2012) Parliamentary control of the security sector in Republic Serbia. Belgrade: Faculty of Security.

\section{Papers, journals and sourses taken from web sides}

1. Buchkoski, V. "Open List". Dnevnik. The 17th February 2012.

http://otvorenilisti.org/?p=1458, [visited on 21.08.2016]

2. Blazevska, K. "Parliamentarians of Gruevski blackmailed with draft guarantees and Blanco resign!". Deutsche Welle. The 9th March 2015.

http://dw.com/p/1EnU9, [visited on 08.18.2016]

3. Democratic Centre of Security Development and the Rule of Low. (2003) Oversight and Guidance: The Relevance of Parlamentay Oversight for the Security and its Reform, Brussels/Geneva: DCAF, NATO Parliamentary Assembly.

4. How to start functioning system of actuators and brakes in Macedonia Dialogues vision. (2016) Skopje: British Embassy.

http://www.epi.org.mk/docs/D4V_Democracy\%20and\%20Rule\%20of\%20Law_ mk.pdf, [visited on 11.08.2016]

5. Karakamiseva, T. (2008) Basic records systems of organization of government and the need for reform of the political institutions in the country, reform institutions and its importance for the development of the Republic of Macedonia. Skopje: Proceedings of scientific debate, book 5 .

http://www.peacepalacelibrary.nl/ebooks/files/343035197.pdf, [visited on 18.08.2016]

6. "Parliament does not approve the amendments to the lawmakers". Radio Free Europe. The 11 November 2011. http://www.slobodnaevropa.mk/a/24387553. html, [visited on 08.18.2016]

7. Shishovski J. et. al. Efficient Assembly, strong democracy - a vision to improve the system of actuators and brakes in Macedonia, Framework of public policies.

http://www.epi.org.mk/docs/EPI_Ramka\%20za\%20politiki\%20_SSHS.pdf, [visited on: 09.08.2016]

\section{Legal sourses}

1. Constitution of the Republic Macedonia, State Journal of R. Macedonia no. 52/91.

2. Law on parliamentarians, "Public Journal of R. Macedonia "no. 84/05, 161/08, $51 / 11,109 / 14,35$ 